\title{
Conditionality and trade union action in the promotion and defence of workers' rights The Spanish case
}

\author{
Fernando Elorza Guerrero* \\ https://orcid.org/0000-0002-2872-9616 \\ Manuel García Muñoz* \\ https://orcid.org/0000-0002-4243-4355
}

Introduction

It is well known that defining the concept of "conditionality" is a challenging task, given the plural nature of this phenomenon. In fact, the definition will depend on the origin of the person who studies it and the context in which it operates. Nowadays, it is possible to affirm that there is neither a consensus nor even an agreement among economists, sociologists, social science researchers in general, or legal scholars on how to define it (Kock, 2015, p. 98). However, and for the purpose of this work, the reflections presented in the following pages refer to how trade union action in Spain may have been influenced by the conditions established by the European Union (EU) for Spain to access EU financial aid, both during the Eurozone crisis (2010-2013) and during the current Covid-19 pandemic (2020).

In the case of Spain, conditionality is based on a series of parameters that differ from the ones used for other EU member states, such as Greece or Portugal ${ }^{1}$. During the Eurozone crisis (2010-2013), the financial rescue of the above-mentioned countries was articulated through what can be described as "formal conditionality",

Pablo de Olavide University, Sevilla, Spain.

1. This differentiated treatment, depending on the States, is not strange to international practice. Thus, for example, the attitude of the International Monetary Fund when it establishes mechanisms of conditionality related to work is less intrusive in national politics when it comes to States that comply with the standards that are considered typical of a democratic country (see Caraway et al., 2012, pp. 27-61). 
in the sense that the EU documents specified that the rescue was conditioned to the implementation of both social policy cuts and reforms to consolidate the liberalization of the labour market. In contrast, conditionality in Spain was initially informal - imposed through diplomatic action and political pressure - because of the political will to avoid announcing an open intervention and rescue, given the size and weight of Spain within the EU. It only acquired a more formal nature after the bank rescue operation in June 2012 (Gago, 2016, p. 47). In any case, this should not surprise us too much, since historically, and in general, the establishment of labour conditionality policies in the European Union has registered somewhat oscillating applications (Vogt, 2015, pp. 285-304).

On the other hand, the financial rescue designed by the EU to overcome the economic-health crisis created by the Covid- 19 pandemic had, from the beginning, a much more formal nature, as evidenced by the package of measures contained in the European Recovery Plan agreed on by the European Council on 21 July 2020. This instrument is at the origin of the Spanish law that provides the legal foundation for the Plan de Recuperación, Transformación y Resiliencia (Recovery, Transformation and Resilience Plan) of the Spanish Government, i.e., the Royal Decree-Law 36/2020, of 30 December, on urgent measures to modernize the public administration and implement the Government's Recovery, Transformation and Resilience Plan $^{2}$. This plan is the Spanish (formal) response to the formal requirements of the EU for Spain to have access to the up to EUR 140,000 allocated in the framework of the Next Generation EU recovery instrument to relaunch the economy. Those requirements include the implementation of specific legislative reforms aimed at bringing about effective changes in, above all, the country's economic functioning and labour market.

The main objective of this work is to reflect on how a situation that can be described as of political-financial conditionality has affected or modulated the way in which Spanish trade unions, particularly the most representative ones, have operated during both crises, and, ultimately, on the extent to which trade union action, in a broader sense, may have been influenced by it. The interest of this reflection lies in that, in general terms and independent of all considerations made in these pages, during the Eurozone crisis Spanish trade unions were excluded from the design of the adjustment measures, which led to theirs and other social organizations' confrontation with the Government, whereas during the Covid-19 crisis, they have, from the beginning, been acknowledged as active agents in the design of policies to overcome the crisis. This has led to their occupying a different position, at a mo- 
ment in which social protest movements in Spain have also changed their attitudes in the face of the crisis.

The eurozone crisis (2010-2013)

\section{Conditionality derived from the articulation between Eu and member state regulations}

The EU is a supranational community with legal personality, which has its own sources of law, both material (centres with the capacity of adopting formal and compulsory mandates for all their mandataries) and formal (instruments which contain the mandates issued by the centres entitled to adopt them). The legal order, which comprises EU primary legislation (Founding, Amending and Accession Treaties) and secondary legislation (Regulations, Directives, Decisions and, with no binding power, Recommendations and Opinions), stipulates that member states can participate in the creation of norms with a direct effect on their national legal systems. In some cases (Regulations), it will not be necessary for these systems to make formal acts of reception, while in others (Directives) the transposition of those norms to national law will be required. In both cases, the purpose will be to coordinate internal norms or harmonize regulations, so that they can be applied in the geographical and functional space of the EU. At the same time, the EU legal order stipulates that the member states may encounter some obstacles to the passing or execution of their internal norms, because they have to conform to the EU coordinated or harmonized regulation. In this sense, several principles need to be taken into account, including the principle of primacy of European law, which supersedes national law in those aspects in which the two may collide, or the principle of direct effect of European law, when its transposition is not made within the period or in the terms established.

The constraints increase when conditionality is introduced, because the incorporation of EU law or action by the member states requires that specific reforms be implemented in national law, especially if it involves some kind of concession. Conditionality may, therefore, imply that the internal legislative technique used to implement the reforms departs from the usual practice, based to a greater or lesser extent on the development of social dialogue (the legal materialization of bipartite or tripartite - with the Government - agreements on labour and social protection issues), or is applied without the expected political or social consensus (i.e., the support of other political groups - possibly through their parliamentary votes -, trade unions, employers' organizations, professional associations, civil organizations, etc.). Naturally, the lack of consideration of other parliamentary representations - not necessarily constituted as opposition -, and/ or of citizen participation organizations and, 
most especially, employers' organizations and trade unions in the passing of a norm may cause a reaction from these entities, whether through traditional forms of social and political response, or through new or less usual forms (emergence of new social movements, non-associative organizations, political parties, protests, etc.).

The financial crisis that broke out at the end of the third trimester of 2007 in the Eurozone, although with unequal repercussions for its member states, gave way to a situation that was favourable for the development of conditionality. This was particularly so in relation to those states where the crisis was more intense and which at some point needed, in one form or another, the financial assistance provided by the EU, graphically described with the term "rescue". Spain was hard hit by the crisis, which greatly impacted its financial and economic sphere, but also the employment and social one, and was therefore obliged to adapt its internal legal system, mostly in what respects social matters, to, on the one hand, the demands of the EU and, on the other, the irruption of new social movements and its effect on the political and social sphere.

In the period comprised between the end of 2007 and 2013, at the peak of the crisis, the unemployment rate increased by $17.86 \%$, progressively rising from $8.23 \%$ in 2007 to $26.09 \%$ in $2013^{3}$. Total factor productivity (TFP) had been falling since the mid-1990s, a situation that continued with the introduction of the euro and throughout the crisis years, until it reached $12.5 \%$ in 2014. The per capita income differential between the Spanish and the Eurozone rates was 23.1 points in $2013^{4}$. In addition, inflation began to fall after 2008: 4.22\% (2008), 1.43\% (2008), 0.79\% (2009), 2.99 (2010), 2.38\% (2011), 2.87\% (2012), $0.25 \%$ (2013) . In contrast, the risk premium increased from 5 and 6 points at the beginning of the crisis to 640 points in July $2012^{6}$.

Given the evolution of these data, the EU and its member states, especially Germany, deemed necessary to implement reforms not only to emerge from the situa-

3. The evolution during this period was as follows: $8.23 \%$ (2007), 11.25\% (2008), 17.86\% (2009), $19.86 \%$ (2010), 21.39\% (2011), 24.79 (2012) and 26.09\%. STATISTA, 2021. Retrieved from https:// es.statista.com/estadisticas/500987/prevision-tasa-de-paro-en-espana/. According to the Encuesta de Población Activa (EPA, Economically Active Population Survey) conducted by the Instituto Nacional de Estadística, INE, National Statistics Institute (2021), the data of the fourth trimester in each of those years were: $8.7 \%$ (2007), $13.79 \%$ (2008), 18.66\% (2009), 20.11\% (2010), 22.56\% (2011), 25.77\% (2012) and 25.73\% (2013). Retrieved from https://www.ine.es/prensa/epa_tabla.htm.

4. Fundación BBVA: "La productividad de la economía española cae un 10,5\% desde 1995 frente al crecimiento del 4,5\% que registra la eu", Esenciales, 33: "La productividad de la economía española en el contexto internacional", 21/02/2019. Retrieved from: https://www.fbbva.es/noticias/ productividad-economia-espanola-cae-desde-1995-frente-crecimiento-ue/.

5. Inflation.eu. Worldwide Inflation Data. Retrieved from https://www.inflation.eu/es/.

6. Idealista/News.Retrievedfromhttps://www.idealista.com/news/finanzas/inversion/2017/07/26/747 400-imagen-del-dia-asi-ha-cambiado-la-prima-de-riesgo-desde-que-estallo-la-crisis. 
tion in which the Spanish economy and labour market were already immersed, but also to prevent its intensification and impact on other members states. The Spanish Government, led by the Partido Socialista Obrero Español (psoe, Spanish Socialist Workers' Party), probably considered, despite its resistance to undertake measures that could be contrary to its ideological position, that their implementation could not be avoided and, consequently, inaction or delay were no longer options. The Government was inclined to implement those measures as soon as possible, even if it meant to depart from the formula that had been applied since the end of the 1990s, by which the agreements signed by the social partners to reform labour and social norms were transformed into laws with the corresponding legal qualifications. The Government was aware that this decision would strain its relations with the social partners, and possibly affect the governing party's electoral expectations as well. In effect, the immediate response of the trade unions to the absence of this legislative formula of compromise, based on social dialogue and also known as "weak corporatism" or "mixed market economy" (Gago, 2016, p. 49), was a call for a general strike.

This had happened already several years before, after the publication of the Royal Decree-Law 5/2002, of $24 \mathrm{May}^{7}$, on urgent measures to reform the unemployment protection system and improve employability, which had been promulgated by the Spanish Government then led by the Partido Popular (pp, Popular Party). A general strike was called for June 20, 2002, one day before the Seville European Council meeting of June 21-22. The reform included a series of measures concerning unemployment benefits and dismissals that had been proposed by the Government and presented by the Ministry of Labour and Social Issues on April 17, 2002. In the words of the trade unions CC.OO. and UGT (organizers of the strike, to which other smaller trade unions also adhered), the Government's actions entailed, in both form and content, "the renunciation of dialogue and negotiation, which we, the trade unions, have always defended and practiced in the face of all changes and reforms affecting labour and social rights" ${ }^{\text {. }}$

\section{The first biennium of the financial crisis: 2010-2011}

In the central period of the Eurozone financial crisis, the first action of the Spanish Government, led by the PSOE, when confronted with the economic consequences of the crisis, was encouraged by the EU, most particularly by some member states,

7. $B O E$ (25 May 2002), 125: 18781-18795.

8. UGT-CC.Oo. (16 May 2002), "Resumen de propuestas para la mejora del Empleo y la protección por desempleo”, Madrid, PDF. Retrieved from http://www.juntadeandalucia.es/empleo/anexos/ccarl/35_2. pdf. All translations of quotes from Spanish into English hereinafter are by the authors. 
and consisted in the introduction of a set of extraordinary measures to "accelerate, in 2010 and 2011, the deficit reduction initially envisaged", as established by the Royal Decree-Law 8/2010, of 20 May, on extraordinary measures to reduce public deficit $^{9}$. The measures included the reduction, in consonance with the principle of gradual implementation, by an annual 5\% of the total payroll of the public sector body; the suspension of the revalorisation of pensions, except for the minimum and non-contributory ones during 2011; the elimination of retroactivity in the payment of dependency benefits computed from the application date, unless notice of the decision on the application is not issued within the six-month period established, in which case, retroactivity would be applied from that day onwards; the abolition after January 1, 2011 of the benefit of EUR 2500 for every birth or adoption; the revision of the price of medicines and the adjustment of the number of units per box to reduce the pharmaceutical expenditure, as well as other measures to guarantee the contribution of the local bodies to the social consolidation effort and to improve the supervision of their economic and financial management and of public expenditure in general. In the same spirit, before a month had passed from the publication of this norm, the Government promulgated Royal Decree-Law 10/2010, of 16 June, on urgent measures to reform the labour market ${ }^{10}$. The main objectives of this norm were "to contribute to the reduction of unemployment and to increase the productivity of Spanish economy" through reforms aimed at bridging the duality of the Spanish labour market, reinforcing labour flexibility instruments - reduced working hours rather than dismissal of the worker, for instance -, developing mechanisms for the adaptability of firms other than temporary recruitment, and increasing the employment rate, especially among the younger population, by reorganizing the benefits for permanent recruitment and improving labour mediation.

The reaction of the trade unions UGT, CC.OO. and CGT was immediate and basically translated into a call for a general strike on September 29, 2010, not so much because of the content of these reforms, but for having been excluded from the legislative process and for the abandonment of the previous dynamic of social consultation in favour of unilateralism in the creation of social norms ${ }^{11}$. Nevertheless, the trade unions were probably aware that the regulation of social matters did not depend solely on national policies, but also on EU policies, and, consequently, the protest

9. $B O E$ (24 May 2010), 126: 45070-45128.

10. BOE (17 June 2010), 147: 51662-51699.

11. This situation is not typical only of countries like Spain. Also in Portugal (May 2011), as in many other cases, the Troika imposed on this country a severe fiscal consolidation program that implied the direct intervention of the socio-economic governance mechanisms by European Commission technicians, with the consequent impact on the social dialogue in this country (Costa, 2012, pp. 397-410). 
focused on the expenditure cuts and austerity measures that were being imposed as an antidote against the crisis within the EU, especially in the member states that were more sensitive to conditionality. Thus, the Spanish Government did not identify itself as the direct target of the trade unions' pressure, but as an indirect one for having assumed the policies that the EU considered appropriate to stop the financial crisis and start the path towards recovery (Gago, 2016, p. 57). For this reason, it was not surprising that, soon afterwards, on February 2 the following year, the Government and the social partners (CC.OO., UGT, CEOE and Cepyme) signed the Acuerdo Social y Económico para el Crecimiento, el Empleo y la Garantía de las Pensiones (Social and Economic Agreement for Growth, Employment and Guaranteed Pensions), which underlined the importance of social dialogue and the need to resume it and reinforce it for the purpose of configuring labour and social regulations. Thus, the foundations for the reform of the Social Security system were laid, particularly with respect to pensions, active employment policies and other labour-related issues, as was the agreement between, on the one hand, the Government and the trade unions on matters concerning the civil service, and, on the other, the employers' organizations and the trade unions on the reform of collective bargaining.

Nevertheless, seven days before, on January 25, 2011, the plenary session of the Congress of Deputies, had approved a "report for the evaluation and reform of the Toledo Pact", which had been drafted by the non-permanent parliamentary commission for the monitoring and evaluation of the agreements of the Toledo Pact, and which expressly pointed out that "once the recommendations are approved, their implementation is not only a task for the legislative power, but rather one in which, together with the Government, trade unions and employers" organizations are - given the labour and social security-related nature of the recommendations - relevant actors ${ }^{{ }^{12}}$. The lines of reform of the Social Security system contained in the recommendations of this report triggered the call for a general strike on January 27, 2011 made by the regional trade unions (ELA, LAB, CIG and others) in their respective territories (Galicia, Navarra, the Basque Country and Catalonia), and by the nation-wide organizations CGT and CNT ${ }^{13}$, but not by the larger trade unions UGT and CC.OO., which at that very moment were negotiating the above-mentioned agreement of February 2. As a result, the strike was not widely supported ${ }^{14}$. On the basis of this agreement and of the above-mentioned report, the Government finally enacted Law 27/2011, of 1 August, on the updating,

12. Boletin Oficial de las Cortes Generales, BOCG, Official Gazette of the Spanish Parliament. (31 January 2011), Congress of Deputies, Series D: General, 523: 32.

13. Collaborators of Wikipedia. (2020), "General strikes in Spain [online]". Wikipedia, the Free Encyclopaedia.

14. El Pais, published on $27 / 01 / 2011$. 
adaptation and modernization of the Social Security system ${ }^{15}$, which, in addition to other parametric reforms, progressively increased, for the first time in the history of Spanish social protection, the ordinary retirement age from 65 to 67 years.

\section{The second biennium of the financial crisis: 2012-2013}

The resumption of the social dialogue with the Government, materialized in the agreement of February 2 and its subsequent legal translation into the abovementioned norm, did not prevent the electoral defeat of the political party (PSOE) that had supported it in the general election of November 20, 2011, in which its main opponent, the PP, obtained an absolute majority and its best election result, in contrast with the worst for the socialist party since the beginning of the democratic period. From that moment onwards, due to the economic data and, building on them, the insistence of the EU, which, mostly through diplomatic actions, claimed the need to undertake the reform of certain labour aspects, the new Government passed the Royal Decree-Law 3/2012, of February 10, on urgent measures to reform the labour market ${ }^{16}$. This law was the result of the unilateral action of the recently constituted Government and, therefore, not the outcome of any social dialogue process, despite the fact that, only a few days earlier, on January 25, 2012, the II Acuerdo para el Empleo y la Negociación Colectiva 2012, 2013 y 2014 (Second Agreement on Employment and Collective Bargaining for 2012, 2013 and 2014) had been signed by the employers' organizations CEOE and Cepyme, and the major trade unions CC.OO. and UGT ${ }^{17}$. This reform, as expressed in the norm itself, aimed at providing "economic and labour operators with a horizon of legal security and confidence in which to develop their activities with certainty to contribute to the creation of jobs". This should allow achieving "a balance between internal and external flexibility; between permanent and temporary recruitment regulations; between the internal mobility of an enterprise and its dismissal mechanisms; between the tutelage to which labour contracts are subjected and the ones operating in the labour market etc.", for the purpose of reaching "the objective of flexisecurity". In this sense, the document introduced a series of measures to "promote the workers' employability", "permanent recruitment and other forms of work" in order "to encourage recruitment by small and medium-sized enterprises and of young people", "to stimulate internal flexibility within the enterprise as an alternative measure to the destruction

15. BOE (2 August 2011), 184: 87495-87544.

16. BOE (11 February 2012), 36: 12483-12546.

17. Published by decision of the Directorate General of Employment of 30 January 2012 (воЕ of 6 February). 
of jobs", and, finally, "to improve the efficiency of the labour market as an element linked to the reduction of labour market dualism, as measures that mainly affect the termination of labour contracts". After the parliamentary procedure, this Royal Decree-Law became Law 3/2012, of 6 July, on urgent measures to reform the labour market ${ }^{18}$, which, including its later modifications, is still in force.

The trade union reaction was identical to that of previous occasions in which the social consultation was ignored before the passing of a norm or regulation, and consisted in the first general strike that the new Government had to face. It was called for March 29, 2012, by national organizations (USO, CGT and CNT), including the most representative ones (CC.OO. and UGT), and regional trade unions (ELA, LAB, CIG), among other organizations. The impact of this protest was, in the Government's opinion, moderate, with 800,000 demonstrators and greater support from the industry than from the trade and services sectors, which did not fully stop their activity. In contrast, the trade unions concluded that the protest had received major support and had been followed by $77 \%$ of the workers. In the words of the leader of UGT, Cándido Méndez, the Government had only two options: "to change or to change the labour reform", because, according to Ignacio Fernández Toxo, the leader of CC.oo., it was "losing most of its credit"

However, given the do-nothing response of the Government to the trade union and social demands, some months later, the most representative trade unions, UGT and CC.OO., together with other of national (USO, CGT, CNT) and regional scope (CIG, COS), called for another general strike on November 14, 2012, coinciding with similar initiatives organized in Portugal, Italy, Greece, Cyprus and Malta. This simultaneous protest action in several countries was perceived as "the first international strike of the $21^{\text {st }}$ century and the first European general strike"20.

However, the Spanish Government did not modify its position, which was actually reinforced - or we could say even imposed - by the Spanish request and the EU's acceptance to provide financial support in exchange for compliance with the commitments and obligations related to the Excessive Deficit Procedure (EDP) and with the recommendations to correct macroeconomic imbalances under $\mathrm{EU}$ supervision. Moreover, it unwaveringly implemented the set of measures deemed necessary to fulfil those obligations ${ }^{21}$. Among those measures, it passed Royal

18. BOE (7 July 2012), 162: 49113-49191.

19. RTVE. Retrieved from https://www.rtve.es/noticias/elecciones/generales/2011/.

20. Collaborators of Wikipedia, 2020.

21. Memorandum of Understanding of Financial-Sector Policy Conditionality, signed in Brussels and Madrid on July 23, 2012, and Financial Assistance Facility Agreement, signed in Madrid and Luxembourg on July 24, 2012 bOE of 10 December 2012). 
Decree-Law 28/2012, of 30 November, on measures to consolidate and guarantee the Social Security system ${ }^{22}$. This norm "established a new limit for the disposal of assets of the Social Security Reserve Fund and authorized the disposal of the Social Security Reserve Fund during the years 2012, 2013 and 2014 to the extent that it is needed, up to a maximum amount equivalent to the budgetary deficit of the managing bodies and common services of the Social Security system". In addition, it revoked "the indexation of pensions during year 2012 and suspended the revaluation of pensions for year 2013 in the terms established" through the corresponding norm. Pensions were finally uprated by $1 \%$ during 2013 , with "an additional $1 \%$ for those pensions that do not exceed the monthly amount of EUR 1000 or the yearly amount of 14,000 ".

Subsequently, the Government passed Royal Decree-Law 5/2013, of 15 March, on measures to favour the continuity of the working lives of older workers and to promote active ageing ${ }^{23}$, which underlined that the "increase in the retirement age", legally stipulated in 2011, "the extension of active life and the increase in the participation of older workers in the labour market are basic elements for the adaptation and sustainability of pensions" that require the implementation of "measures to facilitate early retirement, partial retirement, the combination of active life and retirement, the fight against fraud, and employment policies". All of which would, at the same time, "allow complying with the Recommendations of the European Council of 10 July 2012 concerning the sustainability of the pension system and the promotion of active ageing".

Finally, at the end of the central period of the financial crisis, the Government promulgated Law 23/2013, of 23 December, regulating the Sustainability Factor and the Index for Revaluation of the Social Security Pension Scheme ${ }^{24}$. As explained in its preamble, the norm fell within the scope of the "European Strategy 2020, which is the reference for the coordination of the economic policies of the EU member states and the sphere from which the policy to guide and coordinate efforts to face the challenge of ageing and its impact on social protection systems is promoted". According to the dispositions of the above-mentioned Law 27/2011, of 1 August, the new law incorporated the "sustainability factor", an instrument to be applied to retirement pensions coming into effect on January 1, 2019 and after, "for the purpose of maintaining the proportionality between the contributions to the system and the benefits expected from it, and guaranteeing its sustainability". Starting from January 
1, 2014, the reference module, which had been used since 1997 for the periodic revaluation of pensions, was modified to replace the consumption price index with another index, determined by the mathematical expression reflected in the law. Through this reform, the Government sought to reduce the macroeconomic cost of the Social Security system in an attempt to maintain its financial balance in the medium to long term. However, Law 6/2018, of 3 July, on the General State Budget for $2018^{25}$, suspended its entry into force until a date no later than January 1, 2023, as deemed appropriate by the commission for the monitoring and evaluation of the agreements of the Toledo Pact. The law also established the revaluation of pensions for 2018 in the terms established by the law on the General State Budget of that year.

The lack of response by the trade unions in the face of these legislative actions especially of the most drastic one, i.e., the general strike, which they had often used before - may probably be explained by the concurrence of several motives. On the one hand, the complex economic, labour and social situation, as shown by the abovementioned unemployment, productivity, risk premium and inflation data. This situation demanded the urgent implementation of reforms that could not, or so it was thought, be delayed by social consultation, which usually requires a slower procedure than the unilateral adoption of measures by the Government through the instrument of the royal decree-law. In addition, the solid absolute parliamentary majority of the ruling political party (PP) conferred the necessary legitimacy or, at least that was the Government's perception, to the implementation of the legal measures deemed pertinent, even without the support of the social dialogue. This was especially so after the signing, in the summer of 2012, of the Memorandum of Understanding between Spain and the EU, popularly known as the "bank rescue", which comprised a series of commitments and obligations that the former needed to meet under the supervision of the latter. On the other hand, trade unions probably thought as well that the above-mentioned election results provided the Government enough social support to develop reforms without their participation, especially when this participation had been somehow questioned by one part of society from the beginning of the financial crisis, due to the appearance of excessive institutionalization or accommodation to political power on the part of these organizations. This perception may have been reinforced by the emergence of social movements outside or not linked to the trade unions, given that the latter were likened by one part of society to the political organizations and accused of being responsible for the financial crisis, its consequences and the lack of action to remedy them. 
Certainly, those social movements, new in their configuration, proposals and forms of protest, displaced to some extent trade union action - which has traditionally focused on the problems of the working population, and not on those of the general public -, as well as the initiatives of political parties with parliamentary representation. However, it seems that those movements, which had spontaneously emerged from certain sectors of civil society that felt particularly harmed by the deterioration of the economy and employment, rather than preserving their original features, have tended to transform themselves into political organizations that are quite similar to their predecessors. Subsequently, they have actively participated in politics, so much so that one of these organizations, having won a strong electoral support, has become an integral part of the current coalition Government, together with one of the most relevant political parties, which has been in office for much of the time since the democratic transition.

The economic crisis caused by the Covid-19 pandemic (2020)

From an institutional perspective, it is possible to affirm that the health crisis caused by the Covid-19 pandemic, which has developed into a severe economic and employment crisis, became official in Spain through the enactment of Royal Decree $463 / 2020$, of 14 March, declaring the state of alarm for the management of the health crisis situation caused by Covid- $19^{26}$. However, almost since the beginning of the crisis, the attitude of the institutions, both national and European, was perceived to be different from the one adopted during the Eurozone crisis, and so was the idea that the implementation of measures to overcome the crisis could not be unilateral, as it was with the austerity measures in the previous crisis.

In Spain, the present Covid-19 crisis has, among other effects, reactivated social dialogue and social consultation between the Government - a coalition of PSOE Unidas Podemos, therefore a left-wing government -, and the most representative trade unions - basically UGT and CC.OO. -, and employers' organizations - CEOE and Cepyme -, even before the formal response of the $\mathrm{EU}$ to the crisis through the European recovery instrument was operative. In fact, less than two months after the declaration of the state of alarm, with the corresponding adoption of exceptional measures, the social partners and the Government reached their first agreement. The I Acuerdo Social en Defensa del Empleo (First Social Agreement for the Protection of Employment), signed on May 8, 2020, proved the willingness of the left-wing Government to grant the social partners a relevant role in the management of the 
crisis $^{27}$. The agreement, the content of which was later integrated into Royal DecreeLaw 18/2020, of 12 May, on social measures for the protection of employment ${ }^{28}$, was the first evidence of a process of social dialogue that, while legitimizing the political action of the Government during the pandemic - which was crucial, considering the complex negotiation to obtain the necessary parliamentary support to the successive emergency decree-laws, due to lack of an absolute majority -, made the social partners co-responsible for the country's economic and employment protection policy.

Social dialogue, abandoned in previous years, was thus resumed in one of its most intense forms: that of the agreements leading to the enactment of legislation negotiated by the Government and the social partners. In fact, it was within the framework of this agreement where the so-called Comisión de Seguimiento Tripartita Laboral (Tripartite Labour Monitoring Commission) was created. Integrated by the Government and the above-mentioned social partners, its purpose was not only to carry out a monthly monitoring of the labour-related measures successively adopted, but to become a space in which the measures proposed by the Ministry of Labour or the social partners to overcome the present crisis could be discussed. In this sense, the commitment with social dialogue was proved by the fact that the signing parties agreed - an agreement translated into a legal norm through the second additional disposition of Royal Decree-Law 18/2020 - on that "the commission must, in all cases, be consulted sufficiently in advance prior to the adoption of measures specified in the first additional disposition", which form the core of the labour-related measures to preserve employment and safeguard the economic activity.

As a result of this social dialogue, in the following months and up to today, three more agreements have been reached that, in all three cases, have continued along the path opened by the first one, pursuing the main objective of implementing measures to protect employment as a guarantee for the future viability of Spanish enterprises. Thus, on June 25, 2020, the Second Agreement for the Protection of Employment was signed, and its content was translated into law through the passing

27. Previously, the Government had issued a first norm for the intervention in the labour sphere, Royal Decree-Law 8/2020, of 17 March, on extraordinary urgent measures to address the economic and social impact of Covid-19 (BOE 18 March 2020, 73: $25853 \mathrm{ff}$.). This norm included some of the proposals made by the social partners in the "Documento de propuestas conjuntas de las organizaciones sindicales CC.OO. y UGT y empresariales CEOE y Cepyme para abordar, mediante medidas extraordinarias, al problemática laboral generada por el incidencia del nuevo tipo de coronavirus" ["Document of joint proposals of the trade unions CC.OO. and UGT and the employers' organizations CEOE and Cepyme to address, through extraordinary measures, the labour problems generated by the incidence of the new type of coronavirus"], which can be consulted in: https://www.ugt.es/sites/default/files/ propuestas_conjuntas_coronavirus_parrafol.pdf.

28. BOE (13 May 2020), 134: $32257 \mathrm{ff}$. 
of Royal Decree-Law 24/2020, of 26 June, on social measures for the reactivation of employment and the protection of self-employment and competitiveness in the industrial sector ${ }^{29}$. Later on, in September 2020, the Third Social Agreement for the Protection of Employment was reached and subsequently transformed into law by virtue of Royal Decree-Law 30/2020, of 29 September, on social measures to protect employment ${ }^{30}$. Finally, on January 19, 2021, the Fourth Social Agreement for the Protection of Employment has been subscribed, and, while this article is being written, awaits its translation into law, just like its predecessors.

The Second Social Agreement - replicated in the above-mentioned Royal Decree-Law 24/2020 - incorporated three additional commitments that enlarged the sphere of social dialogue as defined in the initial agreement. Thus, the fourth additional disposition of the Royal Decree-Law 24/2020 established that, in the shortest time possible, the Ministry of Labour and the social partners were required to meet and discuss several issues related to the granting of unemployment benefits to workers with several part-time contracts within the framework of the temporary labour force adjustment plans implemented as a result of the Covid-19 pandemic. They were also requested to seek a solution for the expiration, during the state of alarm, of the unemployment benefits and subsidies granted to workers who were not affected by a temporary labour force adjustment plan.

Independent of the measures to alleviate the situation of self-employed workers once they resume their activity after the state of alarm is lifted, the sixth additional disposition of Royal Decree-Law 24/2020 established the creation of a "commission to monitor the support measures for the recovery of the activity of self-employed workers in the sphere of the Social Security system". This commission was to be composed of the representatives of the Ministry of Social Security and the most significant self-employed workers' associations: the Asociación de Trabajadores Autónomos (ATA, Self-employed Workers' Association), the Unión de Profesionales y Trabajadores Autónomos (UPTA, Union of Professionals and Self-employed Workers), and the Unión de Asociaciones de Trabajadores Autónomos y Emprendedores (Uatae, Union of Self-employed Workers' and Entrepreneurs' Associations). According to that disposition, the main role of the commission was to monitor and assess the measures for self-employed workers established by the above-mentioned royal decree-law ${ }^{31}$. However, it is also important to point out that, through the constitution

29. BOE (27 June 2020), 178: $45244 \mathrm{ff}$. This agreement basically modulated the extraordinary measures initially implemented by the Government through Royal Decree-Law 8/2020, as well as some of the obligations contracted during the first agreement.

30. Вов (30 September 2020), 259: $82169 \mathrm{ff}$.

31. In addition, the fifth additional disposition of Royal Decree-Law 30/2020 (Third Social Agreement) 
of this commission, the signatories of the Second Social Agreement acknowledged the importance of a social dialogue focused also on the problems that are specifically affecting self-employed workers during the pandemic, as reflected on the participation of associations representing these workers. In fact, the work of the commission has yielded some results beyond the mere monitoring and evaluation of the measures established by the law. Thus, for instance, on January 19, 2021, an agreement was reached to extend until May 31,2021, with some modifications demanded by the self-employed workers' associations that were subject to the corresponding negotiation, the package of aid approved for this group of workers. A new space of social dialogue emerges, which was, in fact, being created even before the Second Social Agreement was signed through the more or less formal conversations maintained by the Ministries of Labour and Social Security with these organizations.

Finally, the fifth additional disposition of the royal decree-law, under the heading "Employment pact", defined the commitment of the Government and the social partners to incorporate, through the dialogue round-tables constituted for this purpose, measures aimed at creating employment. As a result of this commitment, on July 3,2020 , the Government, the employers' organizations and the trade unions reached a new agreement: the Agreement for Economic Reactivation and Employment, which, in line with the previous commitment, had the objective of defining the measures for economic reactivation and employment creation that should enable the recovery of the economy and the labour market in Spain once the pandemic begins to recede. It also intended to send the EU a message of unity and consensus on the willingness to get Spain off the ground, at a moment in which the final decision on the distribution of EU funds for the reconstruction of the badly damaged EU economies was pending.

As pointed out in the introduction to this work, we are already acquainted with the Eu plans for Spain, and with the initial legal response of the Spanish Government to the European Recovery Instrument: Royal Decree-Law 36/2020. But, how is social dialogue evolving?

It is important to underline that we have entered a standby period, waiting for the Spanish Government to send to Brussels the details of the structural reform plan that it needs to implement in order to receive the EU funds. As far as we know, the most controversial aspect of the Government's plan is the future reform of the Social Security pension scheme. Meanwhile, at the end of 2020, the trade unions had a clash with the Government over their disagreement on a further rise of the minimum

entrusted the above-mentioned commission with the monitoring and assessment of the new measures for self-employed workers established by the royal decree-law. 
wage in Spain, and a general strike has been called for February 11, 2021. After this announcement was made, the Government offered to start the dialogue around the labour reform that it had promised to undertake at the beginning of its term.

It is possible to affirm that the action of the most representative trade unions during this period has been characterized by a return to formal social dialogue, in contrast with what happened during the 2010-2013 period. In this sense, and despite the recent clash with the Government, the truth is that the social dialogue dynamic that has allowed adopting measures for the protection of employment and the improvement of the workers and employers' situation during the pandemic is expected to enable further agreements on the measures to overcome the extremely severe social and economic crisis in which the country is immersed today. By resuming the social dialogue initiated at the beginning of this term in office - which began with the constitution of the Psoe-Unidas Podemos coalition Government on January 13, 2020 -, the Government and the social partners would be tackling together the required structural reforms to continue the work that during the turbulent 2020 has yielded some relevant results, including the rise of the minimum wage by $5.5 \%{ }^{32}$, or the enactment of the first law regulating remote working ${ }^{33}$.

\section{Conclusion}

Does the political-financial conditionality of the EU have an influence on the action of Spanish trade unions? The answer is no, or, more specifically, not directly or not decisively ${ }^{34}$.

In effect, as shown in this article, only when the Government considered that the macroeconomic and labour market data made the EU's action unavoidable and that the implementation of legal reforms was so urgent that it could not be delayed by engaging in a social dialogue process, did it disregard this option, and this happened mostly when it could rely on the legitimacy granted by a large electoral victory. At the same time, it seems that the trade unions have only dismissed more drastic actions, namely the general strike, when they felt that the strength of the Government's electoral legitimacy and the severity of the economic and employment data could

32. Approved through Royal Decree 231/2020, of 4 February, establishing the minimum wage for 2020 (BOE 5 February 2020, 31: $10184 \mathrm{ff}$.).

33. It became a law through Royal Decree-Law 28/2020, of 22 September, on remote working ( September 2020, 253: 79929 ff.).

34. Nevertheless, it is important to acknowledge that, as a result of the intensity of the crisis caused by the Covid-19 pandemic, ordinary collective bargaining has in fact been suspended in most sectors (Cruz Villalón, 2020, pp. 242-243). In any case, it is reasonable to expect that the negotiation processes will be resumed once the gravest period of the crisis is over. 
prevent one part of society from understanding those actions, or that they would not be widely or significantly supported.

It is true - as it has been conveniently pointed out in some cases - that during the period known as the Eurozone crisis, the "vigilance of national decision-making by supra-national institutions represented by the Troika has led to the substitution of the national social contract with the European imperative as the legitimizing element in public policy" (González Begega et al., 2015, p. 116). But it is also true that, as soon as the EU modified the unilateral way in which it implemented and supervised the financial rescue plans and adopted a more participatory and dialogic dynamic, the trade unions decided to critically participate in this type of reconstruction processes the way it is more natural for them to do it: through the social dialogue with the Government and the employers' organizations. Consequently, the expectation created during the Eurozone crisis around the interaction between civil society organizations (civic platforms, NGOs, etc.) and trade unions as the new formula for the construction of an alternative to extreme capitalism, has vanished, at least for now. In this sense, we understand that, in the medium term, changes will come from the content and scope of the reforms that may be agreed upon and initiated rather than from the way in which the agreement is reached ${ }^{35}$, because, as pointed out before, as soon as it proves possible, trade unions - and also the Government and the employers' organizations - feel more comfortable operating in a space that they have historically, at least since the Second World War, considered as their own: that of formal social dialogue.

In summary, there has been a return to this peculiar "form of integration between the two great powers operating within the labour relations system, the normative power of the State and the social-legal power of collective autonomy" (social dialogue), as a particular sort of "political exchange" (Moreno Vida, 2019, p. 268) ${ }^{36}$. This way, at least in Spain, a response is being given to the request made by the European social partners - CES, Businesseurope, Ceep and SME United - in their joint statement on the emergency caused by the Covid-19, in the sense that the EU member states should involve their national social interlocutors in the design and implementation of national measures to overcome the crisis ${ }^{37}$. It seems, at least for

35. Although the existence of critical voices that demand, in this case from liberal positions, a more open and less ideological social dialogue that breaks with the existing conception must not be ignored either (Rodríguez Morones, 2016, pp. 217-218).

36. For a better understanding of the keys that characterize this renewed social dialogue, it may be useful to consult: Pérez Rey \& Morán, 2020, pp. 233-244.

37. The statement may be consulted on: https://www.etuc.org/en/document/statement-european-social-partners-etuc-businesseurope-ceep-smeunited-covid-19-emergency (Etuc, 2020). 
now, that the approach set out by the European Economic and Social Committee in its recent Opinion of October 2020: "social dialogue is a key instrument for sound governance of any period of change" has been integrated, and it is therefore "crucial that the EU recovery plan is built on and with the involvement of the social partners at all levels" 38 .

38. It can be consulted on: https://www.eesc.europa.eu/en/our-work/opinions-information-reports/ opinions/social-dialogue-important-pillar-economic-sustainability-and-resilience-economies-taking-account-influence-lively-public. This approach is consistent with the call made by the rwo during its centenary year to value social dialogue as a necessary tool for the design and implementation of the "social contract" between governments and employers' and workers' organizations (Iwo. 2019, Work for a brighter future. Report for the Global Commission on the future of work. Geneva, pp. 42 ff.). 


\section{References}

BoLetín Oficial de las Cortes Generales, BoCG, Official Gazette of the Spanish Parliament. (31 January 2011), Congress of Deputies, Series D: General, 523: 32.

BoletíN Oficial del Estado, BOE, Official State Gazette. (25 May 2002), 125: 18781-18795; (24 May 2010), 126: 45070-45128; (17 June 2010), 147: 51662-51699; (2 August 2011), 184: 87495-87544; (11 February 2012), 36: 12483-12546; (7 July 2012), 162: 49113-49191; (1 December 2012), 289: 83175-83179; (10 December 2012); (16 December 2013), 65: 21441-21474; (26 December 2013), 309: 105137-105144; (4July 2018), 161: 66621-67354; (5 February 2020), 31: 10184 ff.; (14 March 2020), 67: 25390 ff.; (18 March 2020), 73 : 25853 ff.; (13 May 2020), 134: 32257 ff.; (27 June 2020), 178: 45244 ff.; (23 September 2020), 253: 79929 ff.; (30 September 2020), 259: 82169 ff.; (30 December 2020), 341: 126733-126793.

Caraway, T. L.; Rickard, S. J. \& Anner, M. S. (2012), "International negotiations and domestic politics: The case of IMF labor market conditionality". International Organization, 66 (1): 27-61.

CC.oo.; UGT; CEOE \& Cepyme. (Marzo 2020), “Documento de propuestas conjuntas de las organizaciones sindicales CC.OO. y UGT y empresariales CEOE y Cepyme para abordar, mediante medidas extraordinarias, al problemática laboral generada por el incidencia del nuevo tipo de coronavirus". Available at https://www.ugt.es/sites/default/files/propuestas_conjuntas_coronavirus_parrafol.pdf.

Collaborators of Wikipedia. (2020), "General strikes in Spain [online]". Wikipedia, the Free Encyclopaedia. Available at https://es.wikipedia.org/w/index.php?title=Huelgas_generales_en_Espa\%C3\%B1a\&oldid=124601925.

Costa, H. A. (2012), "From Europe as a model to Europe as austerity: the impact of the crisis on Portuguese trade unions". Transfer: European Review of Labour and Research, 18 (4): 397-410.

Cruz Villalón, J. (2020), “Técnicas normativas y aplicativas en las medidas laborales ante el Covid-19 en España”. Revista Ius et Veritas, 61: 228-245.

EL PAís, (27/01/2011). Available at https://elpais.com/hemeroteca/elpais/portadas $/ 2011 / 01 / 27 /$.

Eтuc. (24 mar. 2020), "Statement of the European Social Partners Etuc, BusinessEurope, Ceep, smeunited on the Covid-19 emergency". Available at https://www.etuc.org/en/ document/statement-european-social-partners-etuc-businesseurope-ceep-smeunited-covid-19-emergency.

European Economic and Social Committee. (2020), “Social dialogue as an important pillar of economic sustainability and the resilience of economies taking into account the influence of lively public debate in the Member States (Exploratory opinion at the request of 
the German presidency)". Available at https://www.eesc.europa.eu/en/our-work/opinions-information-reports/opinions/social-dialogue-important-pillar-economic-sustainability-and-resilience-economies-taking-account-influence-lively-public.

FundaCión BBVA. (21/02/2019), “La productividad de la economía española en el contexto internacional". Esenciales, 33. Available at https://www.fbbva.es/noticias/productividad-economia-espanola-cae-desde-1995-frente-crecimiento-ue/.

GAGO, A. (2016), "Crisis, cambio en la uE y estrategias sindicales: el impacto de la condicionalidad en el repertorio estratégico de los sindicatos españoles durante la crisis de la eurozona”. Revista Española de Ciencia Politica, 42: 45-68.

González Begega, S.; Luque Balbona, D. \& Guillén, A. M., (2015), “Gobiernos y sindicatos ante la reforma del estado de bienestar. ¿ Ruptura del diálogo social en la periferia de la eurozona?”. Revista de Economía Crítica, 20: 102-119.

IDEALISTA/NEWS. "Imagen del día: así ha cambiado la prima de riesgo desde que estalló la crisis". Available at https://www.idealista.com/news/finanzas/inversion/2017/07/26/747400-imagen-del-dia-asi-ha-cambiado-la-prima-de-riesgo-desde-que-estallo-la-crisis.

INFLATION.EU. Worldwide Inflation Data. Available at https://www.inflation.eu/es/.

Instituto Nacional de Estadística, INE, National Statistics Institute. (2021), "Encuesta de Población Activa, EPA, Economically Active Population Survey”. Available at https:// www.ine.es/prensa/epa_tabla.htm.

Iwo. (2019), Work for a brighter future. Report for the Global Commission on the future of work. Geneva, pp. $42 \mathrm{ff}$.

Kock, S. (2015), “A typology of political conditionality beyond aid: Conceptual horizons based on lessons from the European Union”. World Development, 75: 97-108.

Moreno Vida, M. N. (2019), “La gobernanza de las relaciones de trabajo”. In: AA.vv. El futuro del trabajo: cien años de la OIT. Madrid, MTM y ss, Ministerio de Trabajo, Migraciones y Seguridad Social, Subdirección General de Información Administrativa y Publicaciones, pp. 233-272.

Pérez Rey, J. y Morán, H. (2020), "El acuerdo social en defensa del empleo: un acuerdo fruto de la responsabilidad de Estado”. Revista de Derecho Social, 90: 233-244.

Rodríguez Morones, A. J. (2016), “El diálogo social en España: desarrollo, crisis y nuevos retos". Revista Internacional y Comparada de Relaciones Laborales y Derecho del Empleo, 4 (4): 192-218.

RTve, Radiotelevisión Española. Available at https://www.rtve.es/noticias/elecciones/generales/2011/.

Statista. (7 ene. 2021), “Tasa de desempleo en España 2000-2020”. Publicado por Rosa Fernández. Available at https://es.statista.com/estadisticas/500987/prevision-tasa-de-paro-en-espana/.

UGT-CC.oo. (16 May 2002), "Resumen de propuestas para la mejora del Empleo y la protec- 
ción por desempleo", Madrid, PDF. Available at http://www.juntadeandalucia.es/empleo/ anexos/ccarl/35_2.pdf. All translations of quotes from Spanish into English hereinafter are by the authors.

Vogt, J. (2015), "A little less conversation: The EU and the (non) application of labour conditionality in the Generalized System of Preferences (GSP)". The International Journal of Comparative Labour Law and Industrial Relations, 31 (3): 285-304.

\section{Abstract}

Conditionality and trade union action in the promotion and defence of workers' rights: the Spanish case

Conditionality, among other aspects, determines that the regulatory development of the countries that make up the European Union can be carried out, as is usual in the social sphere, without the intervention, or at least minimally, of the workers' representatives and entrepreneurs, and also from other political formations in the legislative field. Logically, this absence of social or political participation can promote response actions against them, either traditional (strikes, demonstrations, withdrawal of parliamentary support in adoption of legislative measures etc.), or new types (spontaneous concentrations in public places, general assemblies of citizens without a defined convener, appearance of social and political formations of less visible typology, or other similar ones). The financial crisis unleashed at the end of 2007 and the one derived from the health emergency situation due to the global spread of Covid-19, at the beginning of 2020, have precisely encouraged the use of conditionality in the European Union space. However, the way in which conditionality has been developed in one and another crisis in the Spanish State can be said that it has not been identical. Neither have been the reactions of social and political subjects, because if in the first crisis these subjects have experienced a reduction in their functions of participation or intervention in legislative action and in the proposal of political actions, in the second the possibilities of action have been much more significant, and also their contribution to efforts to overcome the crisis situation.

Keywords: Conditionality; Social dialogue; Labour relations; Economic crisis.

\section{Resumo}

Condicionalidade e ação sindical na promoção e defesa dos direitos dos trabalhadores: o caso espanhol

A condicionalidade, entre outros aspectos, determina que o desenvolvimento regulatório dos países que integram a União Europeia possa ser realizado, como é habitual na esfera social, sem a intervenção, ainda que mínima, dos representantes dos trabalhadores e empresários, assim como de outras formações políticas no campo legislativo. Essa ausência de participação social ou política pode promover ações de resposta, sejam tradicionais (greves, manifestações, retirada de apoio 
parlamentar na adoção de medidas legislativas etc.), ou novos tipos (concentrações espontâneas em locais públicos, assembleias gerais de cidadãos sem convocador definido, surgimento de formações sociais e políticas de tipologia menos visível ou outras semelhantes). A crise financeira desencadeada no final de 2007 e a provocada pela situação de emergência sanitária decorrente da disseminação global da Covid-19, no início de 2020, têm incentivado precisamente o uso da condicionalidade no espaço da União Europeia. No entanto, as formas como a condicionalidade se desenvolveu em uma e outra crise no Estado espanhol não foram idênticas. Também não foram idênticas as reações dos atores sociais e políticos, pois se na primeira crise esses atores experimentaram uma redução nas suas funções de participação ou intervenção na ação legislativa e na proposição de ações políticas, na segunda as possibilidades de ação foram muito mais significativas, assim como a sua contribuição para os esforços a fim de superar a situação de crise. Palavras-chave: Condicionalidade; Diálogo social; Relações de trabalho; Crise econômica.

Texto recebido em 8/3/2021 e aprovado em 6/4/2021.

DOI: 10.11606/0103-2070.ts.2021.182990.

Fernando Elorza Guerrero is an associate professor of labour law and social security at the Pablo de Olavide University, Spain. E-mail: felogue@upo.es.

Manuel García MuÑoz is an assistant professor of labour law and social security at the Pablo de Olavide University, Spain. Email:mgarmun@upo.es. 